\title{
The Main Characteristics of Migrants
}

\section{ISMO SÖDERLING}

Research Associate

Institute of Migration

At the beginning of 1980 an extensive research project concerning internal migration was begun at the Institute of Migration in Turku, to be completed by the end of 1981 . The other parties in the project are the Central Statistical Office and the Ministry of Labor. Its purpose is to examine intermunicipal migration in 1977-78 according to migration flows. The following migration flows will be distinguished: migration from one rural area to another rural area, from a rural area to an urban area, from an urban area to a rural area and from one urban area to another urban area.

"A functional model of the migration process» provides the framework guiding the study. Here the migration process is examined by means of theoretical concepts concerning welfare. The main aim of this article is to examine the relations between comprehensive theories and component theories describing migration. At the same time, the reasons for choosing a component theory, such as »the functional model of the migration process» as a guideline in directing the study will be presented.

The final part of the article will examine the characteristics of the migrants of 1978 according to official migration statistics. The examination will be performed so that it is possible to compare the results with the corresponding results arrived at by Ritamies concerning the migrants of $1960-65$ (Ritamies 1968, 107-128). This examination will lay the background for the actual migration study, which will be completed later; the assessment of cross-sectional study results will be noticeably facilitated, when it is known how migration, on the one hand, and the characteristics of the migrants, on the other, have developed over the last twenty years.

\section{A critical examination of existing migration theories}

In migration research, the difficulties found in the formation of theories and in written speculation are caused mainly by two factors. First, migration and consequently also migration research take many forms. Thus, the researcher is faced with a completely different research problem when studying internal migration than when he focuses on overseas migration. Another factor interfering with theory formation is that migration involves many fields of science: 
migration has been studied by anthropologists, demographers, social scientists etc. Each has approached the research problem from the standpoint of his own field of science.

Because there are innumerable theories or models ${ }^{1}$ concerning migration, it is necessary for them to be grouped in some manner. Two of the most common bases for the categorization of theories will be presented in the following. ${ }^{2}$

Rogers has divided migration theories into gravitation theories, regression theories and stochastic theories. The gravitation models are based on distance theories, where the central factor in migration is the distance between the area of arrival and the area of departure. Above all, these theories describe the regional distribution of migrants. The regression models are based on pushpull theories, which explain migration as the interaction between two factors. Stochastic migration studies are based on probability theories, which can be further divided into analytic and synthetic theories (Rogers 1965, 3-14).

Another form of division, one more commonly used in Finland, is made according to field of science. Sociological, economic and geographic migration theories are differentiated (e.g. kom. miet. 1970: B 112; Kanniainen 1972; Vartiainen 1978).

The examination which follows conforms to the latter alternative. It must be noted, however, that in reality there is much interaction between the various fields of science.

\section{A comprehensive model of migration versus partial theories of migration}

Most existing migration theories ${ }^{3}$ have mainly been generalizations about migration or its various stages. They have not reached the actual level of theory (at least according to Nagel's first alternative, cf. footnote). The migration researcher looking for new information must make a choice. According to the first alternative he should strive toward a comprehensive, »complete» migration theory. But according to the second alternative, he should abandon the search

1 Here no distinction will be made between model and theory, instead these concepts will be considered synonyms (cf. Hoffmann-Nowotny 1970, 65).

2 The theory categorizations presented here are the most common. A more extensive examination is not possible here because of lack of space. Excellent basic works in this matter are "Migration Theory and Fact» (Shaw 1975) and "Migration» (HoffmannNowotny 1970).

3 Several different concepts concerning the nature of scientific theory exist. According to Nagel a theory can be the same as the organization of scientific results into a systematic whole. Then the formation of a theory is the real aim of research. On the other hand, theory can be, according to Nagel, a mere aid to be used in research (Nagel 1961, 105-152). According to Eskola the purpose of theory is to condense and clarify available knowledge and also to facilitate the use of new information. Thus, according to Eskola, theory is by nature both an aim and a means (Eskola 1971, 149). 
Figure 1. Functional model of the migration process.

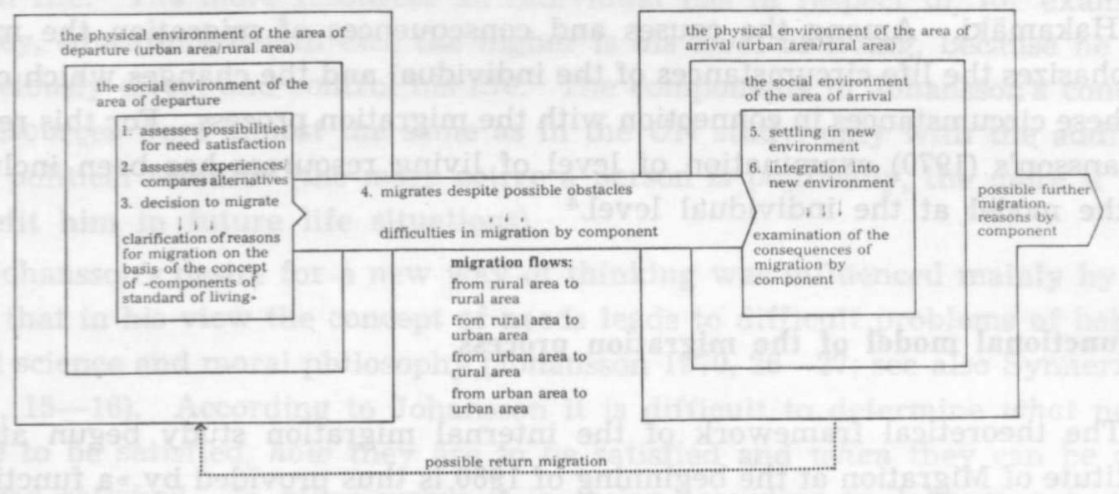

for a general migration theory of this nature and attempt to create increasingly more complete theories concerning the component processes of migration.

Mangalam is probably the best-known representative of the first alternative (the comprehensive model). At the beginning of the volume on migration of which he was editor, he discusses the need for a general migration theory. $\mathrm{He}$ also presented his own migration theory (A General Theoretical Orientation for the Study of Society). The theory is a hypothetical presentation based on the literature, and whose ability to function has not been clarified by its author. In this theory Mangalam has brought forth the changes migration causes in the social organization (which is divided into cultural, social and personality systems) (Mangalam 1968, 12).

The other alternative in developing migration research (abandoning the formation of a general theory) is represented by Hakamäki, among others:

"As the nature of migration becomes more complex, it seems apparent that studies must continue to focus on relatively limited problems. The broader and more varied the clarification of these separate problems is, the more probable it is that we can arrive at distinct generalizations concerning migration. It seems that the foundation of migration research currently consists of individual component and sector theories. It is probably more sensible to speak of the quantity and validity of clarifications made of different components of migration research and of the quantity and validity of generalizations or sector theories based on these clarifications than to speak of a comprehensive migration theory." (Hakamäki 1978, 13; see also Shaw 1975, 6-11).

Evers and Unger (1978), among others, have expressed the same views as Hakamäki. They specifically felt that it was important to develop component theories concerning return migration (Evers and Unger 1978, 5). Hakamäki, on the other hand, did not give preference to any one sector of migration. 
The functional model of the migration process presented in the following section is in accordance with the alternative of sectoral development advanced by Hakamäki. Among the causes and consequences of migration the model emphasizes the life circumstances of the individual and the changes which occur in these circumstances in connection with the migration process. For this reason Johansson's (1970) examination of level of living resources has been included in the model at the individual level. ${ }^{4}$

\section{A functional model of the migration process}

The theoretical framework of the internal migration study begun at the Institute of Migration at the beginning of 1980 is thus provided by »a functional model of the migration process». The model describes the process of migration mainly in regard to the individual. Moving from one place to another cannot be examined as one absolute action; instead it is a process, a long-term happening. Because the area of departure and arrival (the physical environment) is either a rural or urban municipality, four kinds of migration flows will be studied: migration from one rural area to another rural area, from a rural area to an urban area, from an urban area to a rural area and from one urban area to another urban area.

In examining the migration process the reasons for migrating, the difficulties connected with migration and the consequences of migration will be examined using concepts related to the level of living. ${ }^{5}$

Level of living studies are based on the concept of either needs or resources. The best-known of the former is probably the UN study where needs were classified into primary, secondary and tertiary needs. Level of living was defined as follows: the level of living is the satisfaction of the needs of the population assured by the flow of goods and services enjoined in a unit of time (Drewnowski and Scott 1966, 44-46). This definition of level of living used by the researchers was a reaction to economic points of view according to which the level of living is only a synonym for level of consumption (cf. Reisz 1978, 1). Drewnowski and Scott divided level of living into seven components, and this division has remained almost unchanged in later studies also. The components of the level of living were nutrition, housing, health, education, leisure time, security and environmental conditions.

The concept of level of living as resources is based on the viewpoint of Titmuss of England and Johansson of Sweden: if the resources of an individual

4 In addition to Hakamäki, models describing the migration process have also been used by Kultalahti (1972) and Huuhtanen (1975), among others. They did not include a standard of living factor in their description of the process.

5 Here slevel of living» is understood as the operational equivalent of well-being. This is a broad interpretation, for Allardt, for example, considers level of living as one factor of well-being (Allardt 1976). 
are known, one can predict how he will manage in the competitive situations of social life. The more resources an individual has in respect to, for example, money, education, health etc., the higher is his level of living, because he can consciously direct and control his life. The components in Johansson's concept of resources were almost the same as in the UN study, only with the addition of a political resource (the more active a person is politically, the more it will benefit him in future life situations).

Johansson's desire for a new way of thinking was influenced mainly by the fact that in his view the concept of needs leads to difficult problems of behavioral science and moral philosophy (Johansson 1970, 26-27; see also Synnerman 1973, 15-16). According to Johansson it is difficult to determine what needs have to be satisfied, how they are to be satisfied and when they can be considered satisfied. In other words it is easier according to Johansson to gain objective comparative information on the individual's resources than on his needs and level of need satisfaction.

The use of Johansson's resource principle in migration research is supported by several factors. In the following I will examine two of the most important.

1. Johansson prefers to examine poor circumstances rather than good circumstances with his resources; in his opinion it is easier to reach a consensus on the bad points of a matter than on its good points. So for example there is considerable consensus about bad conditions in housing (high housing density), but it is much more difficult to find agreement about the features of an ideal house (Uusitalo 1975, 35).

2. Johansson prefers to study factors which can be manipulated. Because the study will function as a basis for political decision making, there is a temptation to suggest "manipulability» as a criterion in defining priorities. In other words one should try to concentrate the study on problems which can be affected by political decisions, problem areas where ready-built institutions exist through which political decision makers can bring about changes for an individual (Uusitalo 1975, 35).

Because Johansson's concept of level of living only includes things which can be influenced by means of existing institutions, the division of resources mainly follows the classification of different sectors of government (health care, social welfare, education etc.).

Attention has been called to several points in Johansson's resource thinking. Uusitalo's question about how a resource can be recognized as a resource can be considered the most important. According to Uusitalo the division of resources is not based on any commonly known sociological theory (Uusitalo 1975, 31).

This same question has been presented by Roos (1973). He also feels that it is difficult to know to what degree a resource really is a resource and not 
merely a factor connected with consumption (or how, for example, can one know that the consumer uses his household income to his optimal benefit).

Another criticism of the resource principle is that it places too much emphasis on individualism. Here Synnerman suggests the adoption of the concept of a collective resource. The decision to migrate (or to remain where one is) can be influenced by, for example, a road built through the joint efforts of people living in one area, a road which improves mobility and thus also fundamentally increases income and happiness (Synnerman 1973, 10).

Johansson's resource thinking has met the most criticism, as a whole, from Roos and Roos (1977, 20): "The basic ideas of Johansson's approach are interesting but problematic. Johansson's conception of welfare is too simplified and misleading and its implications are completely nihilistic: welfare and level of living are those things which we see around us, nothing more and nothing less.»

At this stage the latest interpretations and further developments of the resource concept will not be examined. Similarly, the relations between the migration process and the level of living at different stages of the migration process will be ignored (see for example, Reisz 1978, 11-19).

\section{The characteristics of internal migrants}

In the following I will make a cursory examination of the characteristics of the migrants of 1978. The comparative data used will be Ritamies's findings concerning the migrants of $1960-65$ (Ritamies 1968). The 1978 data is based mainly on the population statistics of the official Finnish statistics (SVT VIA: 143). Only the information on industrial structure and status are from the ongoing migration study and are thus based on interview data. This data also includes those who migrated in 1977. In presenting the results some of the classifications in Ritamies's tables had to be condensed in order to retain comparability.

First I will present some necessary background information on the development of conditions in Finland as a whole between 1960 and 1978.

A definite change in the industrial structure of the working population has occurred from the beginning of the 1960s to 1978: the proportion working in primary production has diminished while at the same time the proportion working in the service industries has grown (Table 1).

Table 1. The working population, by industry, $\%$

$\begin{array}{lcccc}\text { Industry } & 1960 & 1970 & 1975 & 1978 \\ \text { primary production } & 36 & 20 & 15 & 13 \\ \text { manufacturing } & 31 & 35 & 36 & 35 \\ \text { services } & 33 & 45 & 49 & 52 \\ \text { total } \% & 100 & 100 & 100 & 100\end{array}$


The structural change has clearly been stronger in the rural areas: in the rural areas the proportion of the population working in the service industries increased during the period under study from $21 \%$ to $35 \%$ while correspondingly in the urban areas the increase was from $51 \%$ to $56 \%$.

As the rate of change in the industrial structure slowed down, migration also began to diminish: migration between municipalites grew strongly until 1974, after which the annual number of migrants began to decline (Table 2). The decline in migration has been affected both by the diminishing of potential migrant reserves and also by the economic slump now underway. It must be noted, however, that at the same time that the migration between municipalities has decreased, intramunicipal migration has increased. Thus, the nature of the migration process has experienced a strong transformation.

$\mathrm{Table} 2$. Intermunicipal migration in $1960-78$

$\begin{array}{ccc}\text { year } & \begin{array}{c}\text { number of migrants } \\ \% 0 \text { of the average } \\ \text { population }\end{array} \\ 1960 & 223000 & 50.3 \\ 1965 & 218320 & 47.9 \\ 1970 & 267744 & 58.1 \\ 1974 & 276034 & 58.8 \\ 1975 & 239599 & 50.9 \\ 1978 & 182415 & 38.3\end{array}$

During the period under study the migration gain of the urban areas has turned into a migration loss. The migration gain of the rural municipalities, however, is now definitely smaller than that of the urban areas previously (Table 3).

T a b le 3. Net migration in 1960-65 and 1978, by type of municipality and sex, per 1000 persons of the average population

\begin{tabular}{|c|c|c|c|c|c|c|c|}
\hline $\begin{array}{l}\text { type of } \\
\text { municipality }\end{array}$ & & men & $\begin{array}{l}1960-65 \\
\text { women }\end{array}$ & total & & men & $\begin{array}{c}1978 \\
\text { women }\end{array}$ \\
\hline as & & $\begin{array}{r}+15.4 \\
-\quad 9.8\end{array}$ & $\begin{array}{l}+15.2 \\
-11.2\end{array}$ & $\begin{array}{l}+15.3 \\
-10.8\end{array}$ & & $\begin{array}{l}-1.4 \\
+2.0\end{array}$ & $\begin{array}{l}-0.4 \\
+0.5\end{array}$ \\
\hline
\end{tabular}

Migration has also clearly changed regionally: in Southern Finland the migration gain has decreased (see the situation in Uusimaa, Table 4), while at the same time in the traditional migration loss regions the negative development has slowed down (Vaasa province has even shown a migration gain). 
$\mathrm{Ta} \mathrm{ble} \mathrm{4.} \mathrm{The} \mathrm{net} \mathrm{change} \mathrm{in} \mathrm{internal} \mathrm{migration} \mathrm{in} \mathrm{some} \mathrm{important} \mathrm{provinces}$ in $1961-78$, per 1000 persons of the average population

$\begin{array}{lcccccr}\text { province } & 1961-1965 & 1966-1970 & 1971-1975 & 1976 & 1977 & 1978 \\ \text { Uusimaa } & +17.3 & +14.1 & +9.5 & +3.2 & +3.0 & +2.9 \\ \text { Kuopio } & -10.5 & -10.0 & -6.6 & -1.6 & -1.6 & -1.6 \\ \text { Vaasa } & -5.3 & -4.3 & -4.9 & +0.1 & +0.3 & +1.0 \\ \text { Oulu } & -6.2 & -8.1 & -7.1 & -0.7 & -0.0 & -1.4 \\ \text { Lapland } & -2.1 & -9.5 & -8.1 & -0.8 & -1.7 & -1.9\end{array}$

In examining the development of migration according to the direction of migration (in the rural-urban dimension), it can be noted that migration from one rural area to another rural area has decreased significantly (this is connected with the migration loss of the urban areas noted earlier) and the migration between urban areas has increased (cf. Table 5).

\section{The characteristics of the migrants of $1960-65$ and 1978}

Sex

According to Ritamies the migration of women has always been more active in Finland than that of men (Ritamies 1968, 111). Thus, in 1962-65 women composed $53.2 \%$ of the migrants even though at the same time their proportion of the population was $51.8 \%$. In 1978 the situation had leveled out, for among both migrants and also the population as a whole the porportion of women was the same $(51.7 \%)$.

It was already noted previously that migration from one rural area to another rural area has decreased and interurban migration had increased. The changes are similar among both sexes. Because there were no differences

$\mathrm{T}$ a b le 5. Internal migration, according to migration flow and sex, in 1962 -65 and $1978, \%$

$\begin{array}{lcccccr}\text { migration direction } & \text { men } & \begin{array}{c}1962-65 \\ \text { women }\end{array} & \text { total } & \text { men } & \begin{array}{r}1978 \\ \text { women }\end{array} & \text { total } \\ \begin{array}{l}\text { from rural area } \\ \text { to rural area }\end{array} & 26 & 26 & 26 & 13 & 13 & 13 \\ \begin{array}{l}\text { from rural area } \\ \text { to urban area }\end{array} & 32 & 33 & 32 & 24 & 25 & 24 \\ \begin{array}{l}\text { from urban area } \\ \text { to rural area }\end{array} & 20 & 19 & 20 & 26 & 25 & 26 \\ \begin{array}{l}\text { from urban area } \\ \text { to urban area }\end{array} & 22 & 22 & 22 & 37 & 37 & 37 \\ \text { total \% } & 100 & 100 & 100 & 100 & 100 & 100\end{array}$


between sexes in $1962-65$ when examined by migration flows, neither were there any in 1978 (see Table 5).

Ritamies considered migration within a province short-distance migration. In the beginning of the 1960 s short-distance migration made up $55 \%$ of all migration, but in 1978 it already composed $64 \%$. This is a clear indication of the change in the nature of migration; previously people migrated far away and migration often meant changing jobs or looking for a new job. Now instead, people move shorter distances and the reasons for moving are associated more often than before with housing and the living environment.

Ravenstein observed already in 1885 that short-distance migration was more typical of women. Several other researchers have presented the same finding (Ritamies 1968, 113). Such was the case in 1978 also, although the difference between the sexes in this respect was small $(65 \%$ of the men and $64 \%$ of the women were short-distance migrants).

Age

Most researchers are agreed that migrants are younger than the population on the average (Ritamies 1968, 114). This was the situation in both time periods (Table 6).

The average age of the migrants has risen during the period under study by one year; in $1962-65$ the migrants were 24.2 years old on the average, while in 1978 they were 25.2 years old. At the same time, however, the average age of the population as a whole has risen by almost four years, so that compared to the rest of the population migrants are now definitely younger.

In earlier studies women have been found to migrate at a younger age than men (Ritamies 1968, 114). This was also true of Finland in 1978. In 1962-65, though, the situation was different, for then women at the time of migration

Table 6. The age distributions of the migrants and the entire population, according to sex, in $1962-65$ and $1978, \%$

$1962-65$

age

$\begin{array}{rl}-14 & 29 \\ 15-24 & 25 \\ 25-34 & 26 \\ 35-44 & 10 \\ 45- & 10\end{array}$

total $\%$

average

age/years

\section{ahtant entire}

men women total population

$29 \quad 25$

$25 \quad 34$

$26 \quad 21$

$10 \quad 9$

$10 \quad 11$

100

23.9

\section{7}

30

23

9

11

100

100

24.6

24.2

$\begin{array}{rr}28 & 22 \\ 17 & 24 \\ 13 & 36 \\ 13 & 9 \\ 29 & 9 \\ 100 & 100\end{array}$

1978 
were 24.6 years old on the average, while men were 23.9 years old. The changes between the sexes also appear distinctly when examined by migration flows: while women in 1962 - 65 were older than men in all migration flows, in 1978 the situation was completely the opposite (Table 7).

$\mathrm{T} a \mathrm{ble}$. The average age of migrants, according to migration flow and sex, in years

\begin{tabular}{|c|c|c|c|c|c|c|c|c|}
\hline sex & $\mathrm{Ua} / \mathrm{Ua}$ & $\begin{array}{c}196 \\
\mathrm{Ua} / \mathrm{Ra}\end{array}$ & $\begin{array}{l}-65 \\
\mathrm{Ra} / \mathrm{Ua}\end{array}$ & $\mathrm{Ra} / \mathrm{Ra}$ & $\mathrm{Ua} / \mathrm{Ra}$ & $\mathrm{Ua} / \mathrm{Ua}^{1}$ & $\mathrm{Ra} / \mathrm{Ua}$ & $\mathrm{Ra} / \mathrm{Ra}$ \\
\hline men & 24.3 & 23.8 & 24.0 & 23.6 & 25.9 & 24.5 & 25.9 & 24.5 \\
\hline women & 25.3 & 24.2 & 25.0 & 23.9 & 25.7 & 23.8 & 25.9 & 24.4 \\
\hline
\end{tabular}

\section{Marital status}

In examining the relationship between internal migration and marital status Ritamies formed distributions of all migrants. In order to maintain comparability, persons under 15 years of age have now been removed from her sample.

At the beginning of the $1960 \mathrm{~s} 57 \%$ of the migrants were married and at the end of the $1970 \mathrm{~s} 54 \%$ were married. The change is more pronounced by the fact that the latter figure also includes persons living together in a consensual union. At neither time did the proportion of married persons differ significantly from that of the population as a whole; for example, in $197856 \%$ of all persons in Finland over the age of 15 were married (and $54 \%$ of the migrants). In examining by migration flow, the clearest change in relation to marital status has occurred in migration between urban areas; in this migration flow the proportion of the unmarried has definitely increased (Table 8).

Table 8. The proportion of married migrants in the various migration flows, $\%$ of migrants over the age of 15

$\begin{array}{lccccc}\text { time period } & \mathrm{Ua} / \mathrm{Ua} & \mathrm{Ua} / \mathrm{Ra} & \mathrm{Ra} / \mathrm{Ua} & \mathrm{Ra} / \mathrm{Ra} & \text { total } \\ 1962-65 & 61 & 65 & 48 & 60 & 57 \\ 1977-78 & 54 & 63 & 46 & 55 & 54\end{array}$

\section{Industrial structure}

It was already noted earlier that during the period under examination, a significant transformation has occurred in the industrial structure of the entire population: the proportion employed in primary production has decreased while 
at the same time the proportion in the service industries has increased. The same has occurred in the industrial structure of the migrants (Table 9).

Ritamies noted that persons working in primary production do not migrate as much as could be presupposed by their share of the entire population. On the other hand, those working in the service sector were overrepresented at that time among the migrants (Ritamies 1968, 119). The situation in 1978 is similar. In the service occupations the difference between migrants and the rest of the population has clearly evened out during the period under study.

$\mathrm{Table} 9$. Internal migrants and the entire population in $1962-65$ and in 1978 , by industry, \%

\begin{tabular}{lccccc} 
& \multicolumn{2}{c}{$1962-65$} & & \multicolumn{2}{c}{1978} \\
industry & $\begin{array}{c}\text { internal } \\
\text { migrants } \mathbf{1}\end{array}$ & $\begin{array}{c}\text { entire } \\
\text { population }\end{array}$ & $\begin{array}{c}\text { working } \\
\text { population }\end{array}$ & $\begin{array}{c}\text { internal } \\
\text { migrants }\end{array}$ & $\begin{array}{c}\text { working } \\
\text { population }\end{array}$ \\
primary production & 15 & 35 & 36 & 5 & 13 \\
manufacturing & 39 & 35 & 31 & 36 & 35 \\
services & 46 & 30 & 33 & 59 & 52 \\
total $\%$ & 100 & 100 & 100 & 100 & 100
\end{tabular}

1 cases where industry is not known or where the individual has no occupation have been removed

In examining the industrial structure of the migrants according to migration flow, the greatest change can be seen in migration from one rural area to another rural area. Previously in this migration flow, one-third came from primary production, but in 1978 only $12 \%$ (Table 10). The increase in this migration flow has come specifically from the service industries, for the proportion in manufacturing has remained relatively unchanged. In sum it can be stated that (due mainly to the change in migration from one rural area to another) in 1978 the industrial structure distributions in the various migration flows are clearly more similar than at the beginning of the $1960 \mathrm{~s}$.

T a ble 10. Internal migrants in 1962-65 and in 1978, according to industry and migration direction, $\%$

$\begin{array}{lcccccccc}\text { industry } & \mathrm{Ua} / \mathrm{Ua} & \mathrm{Ua} / \mathrm{Ra} & \mathrm{Ra} / \mathrm{Ua} & \mathrm{Ra} / \mathrm{Ra} & \mathrm{Ua} / \mathrm{Ua} & \mathrm{Ua} / \mathrm{Ra} & \mathrm{Ra} / \mathrm{Ua} & \mathrm{Ra} / \mathrm{Ra} \\ \begin{array}{l}\text { primary } \\ \text { production } \\ \text { manu- }\end{array} & 2 & 8 & 13 & 33 & 2 & 3 & 9 & 12 \\ \text { facturing } & 42 & 48 & 43 & 28 & 34 & 42 & 32 & 31 \\ \text { services } & 56 & 44 & 44 & 39 & 64 & 55 & 59 & 57 \\ \text { total } \% & 100 & 100 & 100 & 100 & 100 & 100 & 100 & 100\end{array}$

1 The table does not include cases where the industrial field is not known or where the person has no occupation 


\section{Status}

During the period under examination a definite change has occurred in the status of the migrants. Among the migrants of 1961-65 the largest group clearly were blue-collar workers. In 1978 the situation had changed, for the smallest number of migrants belonged to this status group. The change has occurred concurrently with the third-status group (other migrants) in particular, for their share has increased in the same proportion. In this connection it is impossible to say, without a closer investigation, to what degree the growth of the third-status group has been affected by the increased migration of students and elderly people.

The share of the third-status group has shown relatively steady growth in each migration flow. Thus no significant changes in the interrelations of the migration flows have occurred during the period under study in relation to status (Table 11).

$\mathrm{Table}$ 11. Internal migrants in $1962-65$ and in 1978 , according to status and migration direction, $\%$

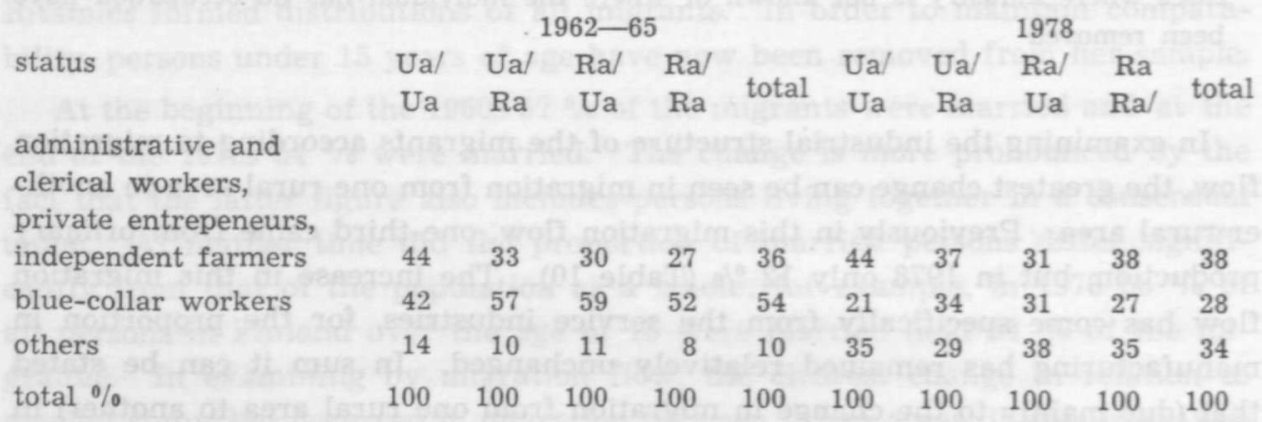

\section{Summary}

The article provides the background for the internal migration study begun at the Institute of Migration in Turku. First, the theoretical basis of migration research was examined and it was shown that a comprehensive model describing migration was unrealistic in directing the advancement of migration research. As an alternative the use of a component theory describing migration was proposed. The framework of the internal migration study of the Institute of Migration is formed by »a functional model of the migration process», which describes the development of the migration process in different migration flows. Johansson's well-being theory has been added to the model; in accordance, the reasons for migration, difficulties connected with migration and the consequences of migration will be examined using living standard components. 
Finally, the article examined changes which had occurred in the characteristics of the migrants. Information from 1978 was compared to the results obtained by Ritamies (1968) concerning the migrants of $1960-65$. In this connection it was observed that there is no reason to distinguish changes which have occurred in migration from the rest of social development. Therefore the great changes which had occurred in the industrial structure of the entire population during the period under examination were noted: the proportion employed in primary production had decreased from $35 \%$ to $15 \%$ while at the same time the proportion in the service industries had correspondingly increased. The fundamental transition in the industrial structure was reflected also in the quantitative development of migration: until 1974 migration between municipalities grew annually.

Characteristic of the migration of $1961-65$ was the clear migration gain experienced by the urban areas. In 1978 the situation was the opposite. The migration gain of the rural areas, however, was definitely smaller than that of the urban areas at the beginning of the 1960s. Related to this, the migration gain felt by Southern Finland has decreased and the losses in the traditional migration loss areas have decreased (Vaasa province was found to have actually experienced a migration gain).

In examining migration flows it was found that migration from one rural area to another had decreased most strongly, while migration between urban areas had increased.

It was noted that migration was increasingly short-distance migration; while $55 \%$ of migration at the beginning of the 1960 s occurred within one province, in 1978 the corresponding figure was already $64 \%$.

The most essential results in comparing the characteristics of the internal migrants of $1960-65$ and 1978 can be condensed briefly as follows:

- Ritamies noted for 1960-65 that women were overrepresented among migrants. In 1978 no differences in this respect were apparent, for there was an equal proportion of women among migrants as in the population as a whole.

In examining migration flows, it was noted that no changes had occurred in either cross-sectional time period in the proportions of the sexes in any migration flow. Thus, for example, the decrease in migration from one rural area to another concerned both sexes to the same extent.

- The migrants of 1978 were an average of one year older than those of 1962 65. However, compared to the entire population the migrants of 1978 were clearly younger, for during the period under study the average age of the population had risen by almost four years.

- It was shown that the proportion of unmarried migrants had increased distinctly: at the beginning of the 1960 s single persons made up $43 \%$ of the migrants, while in 1978 they formed $46 \%$. The change is more pronounced 
because in the latter time period the married group also included those who were living together in a consensual union.

- At the beginning of the 1960 s people working in primary production did not migrate to the same extent as could be presupposed by their proportion of the whole population. On the other hand, people working in the service sector were overrepresented among the migrants. In 1978 the situation was similar; however, those employed in the service industries were no longer as clearly overrepresented as before.

Definite changes were observed when migration was examined according to migration flows. In rural-rural migration the proportion working in primary production decreased from $33 \%$ to $12 \%$. Related to this was the fact that the migration flows of 1978 are clearly more uniform when examined by industry.

- An examination according to status showed that the proportion of bluecollar workers among the migrants had definitely decreased. An increase had occurred specifically in the "others"-migrant group. This transition is probably related to the increased migration of students and pensioners. This third status group was found to have grown steadily in every migration flow.

\section{References}

Allardt, Erik: Hyvinvoinnin ulottuvuudet. Porvoo 1976.

Bogue, Donald: Principles of Demography. New York 1969.

Drewnowski, Jan - Scott, Wolf: The Level of Living Index. UNRISD Report no 4. Geneva 1966.

Eskola, Antti: Sosiologian tutkimusmenetelmät I. Porvoo 1971.

Evers, Hans-Dieter - Unger, Klaus: Remigration and Social Structure. Bielefeld 1978. Hakamäki, Simo: Maaseudulta muutto muuttoliikkeen osana. Jyväskylän yliopisto. Jyväskylä 1978.

Hoffmann-Nowotny, Hans-Joachim: Migration. Stuttgart 1970.

Huuhtanen, Pekka: Muuttajan muotokuva ja sopeutuminen. Työvoimaministeriö, Suunnitteluosasto, monistettuja tutkimuksia 11. Helsinki 1975.

Hägerstrand, Torsten: Migration and Area. Lund 1957.

Johansson, Sten: Om levnadsnivåundersökningen. Stockholm 1970.

Kanniainen, Vesa: Työttömyys ja muuttoliike Lapin läänissä 1960-luvulla. Työvoimaministeriö, Suunnitteluosasto, monistettuja tutkimuksia 3. Helsinki 1972.

Komiteanmietintö 1970: B 112. Siirtolaisuustutkimusten ohjelmointitoimikunnan mietintö. Helsinki 1970.

Kultalahti, Olli: Muuttaminen sosiaalisena ilmiönä. Acta Universitatis Tamperensis, ser. A vol. 46. Tampere 1972.

Lee, Everett S.: A Theory of Migration. Demography 3/1966.

Mangalam, J. J.: Human Migration. Lexington 1966.

Nagel, Ernest: The Structure of Science. London 1961.

Mather, P. M. - Openshaw, S.: Multivariate methods and geographical data. The Statistician, vol. XXIII, Nrs $3 / 41974$. 
Ravenstein, E.: The Laws of Migration. Journal of the Royal Statistical Society, 48, 1885.

Reisz, Björn Andersen: Flytting og levevilkor. NordREFO 1978: 3. Oslo 1978.

Ritamies, Marketta: Maassamuuttajien ominaisuuksista. Väestöntutkimuksen vuosikirja 10. Vammala 1968.

Rogers, Andrei: An Analysis of Interregional Migration in California. Berkeley 1965.

Roos, Jeja Pekka: Welfare Theory and Social Policy. A Study in Policy Science.

Commentations Scientiarum Socialum, Vol. 4, 1973. Helsinki 1973.

Roos, Jeja Pekka - Roos, Barbara: The Way of Life in Social Change. A Comparative Study. Working Papers 1. Joensuu 1977.

Shaw, R. Paul: Migration Theory and Fact. Philadelphia 1975.

Stouffer, Samuel: Intervening Opportunities. American Sociological Review, no 5/1940.

Synnerman, Jan Erik: Vilhelminaundersökningen. Umeå 1973.

Taylor, R. C.: Migration and Motivation: A study of determinants and types. Teoksessa: Jackson, J. E. (ed.): Migration, s. 99-133. Cambridge 1969.

Thomas, Dorothy: Research Memorandum on Migration Differentials. New York 1938.

Uusitalo, Hannu: Income and Welfare. Research Group for Comparative Sociology. Helsinki 1975.

Vartiainen, Perttu: Muuttoliiketutkimuksen nykytila ja kehityslinjat - kriittinen katsaus. Terra, 90. vsk. no $3 / 1978$.

Wolpert, J.: Behavioral Aspects of the Decision to migrate. Papers and Proceedings of the RSA, vol. 15, 1965.

Zipf, G.: The P1P2/D hypothesis. American Sociological Review 11/1946. 